\title{
CHARGES REFUNDED BY THE CARRIER RESPONSIBLE FOR DAMAGE TO THE CONSIGNMENT
}

\section{DOROTA AMBROŻUK}

University of Szczecin, Faculty of Management and Economics of Services, POLAND

e-mail: dorota.ambrozuk@wzieu.pl

\begin{abstract}
\begin{tabular}{l|l} 
RECEIVED & 10 December 2018
\end{tabular}
ACCEPTED 28 December 2018

JEL

CLASSIFICATION

$\mathrm{K} 12$

KEYWORDS contract of carriage, carrier's liability, other charges incurred in respect of carriage

ABSTRACT In addition to the payment of compensation for damage to carried goods, some transport regulations also oblige carriers to refund the carriage charges, customs duties and other charges (costs) incurred in respect of the carriage of the goods. However, these provisions do not contain a definition of "other charges incurred in respect of carriage". Thus, in academic studies and judicature it is understood differently. The aim of the article is to present possible solutions in this respect. At the same time, the author indicates which solutions she is in favour of, presenting arguments in support of her position. Comments in this respect are preceded by an explanation of the legal nature of the claim for refund of this expenditure.
\end{abstract}

\section{Introduction}

In accordance with Article 23 (4) of the CMR, in addition to compensation for damage to the goods, the carrier is obliged to refund the carriage charge, customs duties and other charges incurred in respect of the carriage of the goods, in full in case of total loss and in proportion to the loss sustained in case of partial loss, but not other damage shall be payable. An analogous regulation is contained in the provision of Article 82 of the Polish Transport Law Act 
and in the Article $30 \S 4$ of the CIM, which additionally states that the refund does not include excise duties for goods carried under a procedure suspending those duties. However, there is no such regulation in other international transport conventions.

At the same time, these provisions do not contain a definition of "other charges incurred in respect of the carriage". The question then arises as to what should be understood by this term? There are two groups of views on this issue in judicial and literature - one in favour of a narrow and one in favour of a broad approach to this cost.

In order to find the correct meaning of this concept it is necessary to define the legal nature of claim for refund of expenses. Despite some discrepancies in older literature, it seems that this issue has recently been unambiguously resolved (Wesołowski, 2013, p. 536). There is no doubt that, under the provisions in question, the carrier is obliged not only to repay what he himself received in performance of the contract, but also to pay the charges incurred in connection with transport to other persons (forwarder, handling and storage companies, customs and tax authorities) if these expenses have been ineffective because of the damage caused by the goods.

It should be assumed that, as regards the costs incurred for the benefit of the carrier (transport costs, other charges for services related to transport), the claim for their payment is a claim for reimbursement of undue benefit (in Poland Article $410 \S 2$ of the Civil Code), assuming that the basis for the benefit has been eliminated or the intended purpose of the benefit has not been achieved. In the case of costs incurred for third persons, the claim for repayment by carrier is of a compensation nature (see Kolarski, 2002, pp. 151-152; Ambrożuk, 2011, p. 87).

\section{A restrictive understanding of "other charges incurped in respect of carpiage"}

The proponents of the narrow classification of "charges in respect of carriage" are of the opinion that it covers only the expenses (costs) normally incurred in concluding a transport contract and the proper transport of the goods to the place of destination. Their repayment by the carrier sometimes depends on whose benefit they were incurred.

In this context, the following are therefore refundable: the freight forwarder's remuneration, the costs of cargo insurance during transport, expenditure on loading and stowage of goods on the means of transport (e.g. judgment of the German Bundesgerichtshof of 3 July 1974; similarly (Rodière, 1970, p. 315), which stipulated that the repayment is subject to the condition that the activities are carried out by the sender), expenditure incurred in obtaining the required documents.

Such an understanding of the notion under consideration does not make it possible to cover those expenses which are a consequence of the mere fact of damage to the consignment. It is presented primarily in German judicature and literature. Therefore, representatives of this approach speak out against, among others, the refund of, e.g:

- the costs of expert reports (Jesser-Huß, 2009, p. 1079; Koller, 2013, p. 1116; the Oberlandesgericht Düsseldorf in its judgment of 14 March 2007),

- storage, return transport and disposal (utilization) costs (Jesser-Huß, 2009, p. 1079; Koller, 2013, p. 1116); similarly, the Belgian Tribunal de Commerce in Gand in its judgment of 29 June 1999, which refused to recover cost of cleaning and disposal the goods; similarly, the Cour d'Appel in Anvers in its judgment of 17 June 2002, also commented on disposal costs). However, the German Bundesgerichtshof in its judgment of 3 July 1974, considered that the storage costs of the damaged goods should be refunded,

- costs of VAT and excise duties (see: judgment of the Belgian Tribunal de Commerce in Anvers in its judgment of 12 May 1999, judgment of the Polish Sąd Okręgowy in Łódź of 27 October 2017). 


\section{A broad understanding of "other charges incurped in respect of carpiage"}

Some authors argue that the provision obliging the carrier to return "other charges in respect of carriage" should be interpreted broadly but sensibly. In such an understanding, it includes not only the expenses incurred in connection with the conclusion of the contract of carriage but also any expenses (costs) which are incurred as a consequence of damage caused in the consignment by the carrier or persons for which the carrier is responsible. It does not matter for whom (carrier, third party, e.g. forwarder or tax authority) and by whom (sender, consignee) they were incurred. These costs include, but are not limited to, the following:

- excise tax which the entitled person must pay to customs authorities in connection with the loss of goods (e.g. the House of Lords in the judgment of 9 November 1997; the Cour d'Appel in Anvers in the judgment of 29 June 2009; the Polish Sąd Okręgowy in Łódź in the judgment of 31 July 2015),

- VAT which is not refundable in the event of the disappearance of goods (see, for example, the Belgian Cour de Cassation in its judgment of 30 May 2002; the Cour d'Appel in Anvers in its judgments of 15 June 2009 and 29 June 2009; the French Cour de Cassation in its judgment of 15 October 2002; the Paris Cour de Appel in Paris in its judgment of 30 March 1973),

- the costs of expert reports concerning the damaged goods (see: the French Cour de Cassation in its judgment of 15 October 2003; the Cour d'Appel in Poitiers in its judgment of 31 March 1971; the Rechtbank van Koophandel in Mechelen in its judgment of 18 November 1999; the Tribunal de Commerce in Malines in its judgment of 18 November 1999),

- costs of return transport of goods when the consignee refused to collect them because of damage (e.g. the English Queen's Bench Division in the judgment of 22 November 1980, which, however, in an earlier judgment of 20 November 1973, refused to award such expenditure),

- costs of storage of damaged goods (e.g. the German Bundesgerichtshof in the judgment of 3 July 1974).

\section{Attempt to solve the problem}

It is difficult to resolve the issue of a broad or narrow understanding of the scope of this obligation. The CMR (like the CIM) does not provide clear guidance. The provision of Article 6 (1)(i) of the CMR may be helpful to a certain extent. This provision mentions the following as charges relating to carriage transport: carriage charges, supplementary charges, custom duties and other charges from the making of the contract to the time of delivery (the subsidiary role of this provision is noted both in the literature (Wesołowski, 2013, p. 539) and in judicature - the Tribunal de Commerce in Anvers in its judgment of 12 May 1999, the Polish Sąd Okręgowy in Łódź, in the judgment of 27 October 2017, which refused to grant refund of excise duty and stating that the charges incurred in connection with the transport of goods, in order to be refundable, should be similar to that of a carriage charges and customs duty, which are expressis verbis listed in Article 6 (1)(i) of the CMR). Unfortunately, the conclusions drawn from this provision remains limited.

Undoubtedly, only those costs which do not increase the value of goods at the place and time of shipment for transport may be compensated under Article 23 (4) of the CMR (see the Bundesgerichtshof in the judgment of 10 December 2009). The issue of separating the components of the value of goods from the place and time of shipment for transport and the costs associated with transport is not always obvious. This is illustrated by the judgment of the French Cour de Cassation of 5 October 2011, which stated that even if duties on cigarettes are paid 
at destination, such duties should be added to the value of the goods and do not constitute costs incurred in respect of carriage within the meaning of Article 23 (4) of the CMR.

The value of the packaging may be also debatable. As a rule, it is a part of the consignment, so packaging costs should be refunded only if the packaging was used for a specific shipment and did not increase the value of the goods at the place and time of shipment (the Queen's Bench Division judgment of 20 November 1973; conversely, however (Rodière, 1970, p. 315), which assumes that the costs of preparing the consignment for carriage and its packaging are not to be refunded because they add to the value of goods, while (Loewe,1976, pp. 503,568) takes a similar position on costs of preparing the consignment for carriage; on the other hand (Clarke, 2009, pp. 307-308), accepts that all expenses are refundable provided that the carrier could have foreseen them at the time of conclusion of the contract).

It would seem that, a narrow understanding of the notion of "the charges incurred in respect of carriage" which are repayable by the carrier should be upheld. Such an interpretation of the above notion is supported first of all by the linguistic interpretation of the above mentioned regulations, as they indicate the charges incurred "in respect of carriage" and not in connection with damage incurred in the consignment. In interpreting Article 23 (4) of the CMR in particular, the content of Article 6 (1)(i) of the CMR referred to above cannot be disregarded either.

Not less important is the purpose of the provisions concerning the determination of the amount of compensation due from the carrier in the event of damage to goods. The purpose of these rule is to enable the carrier to calculate the risks associated with transport. Contrary to the mere compensation for damage to goods, which is limited in various ways (e.g. by limits on the amount of compensation), the obligation to refund the charges in question is not limited in any way. In some cases, these charges may therefore be much higher than the amount of compensation for damage to the substance of the goods. Therefore, the rules governing their refund should be interpreted strictly. This means that, in principle, only costs that are strictly related to the translocation of the goods should be included within the scope of such charges. These costs are independent of whether the goods have been lost in whole or in part or whether the transport has been carried out correctly and the goods have been delivered to the consignee.

On the other hand, however, there are some arguments in favour of a broader understanding of the provisions in question. Provisions limiting the liability of the carrier are exceptional in nature. Consequently, questionable issues should be resolved in accordance with the principle of full compensation. Repayment should cover charges incurred in connection with activities incumbent on the carrier under the contract (e.g. care for the goods), and activities incumbent on the carrier under regulations (e.g. environmental protection) but not undertaken by the carrier itself for some reason. This includes, for example, the costs of cleaning up the place of accident, the costs of segregation of goods and their reloading and repositioning on the means of transport, as well as intentional costs incurred in order to minimize the damage. This also applies to rescue costs (see the Oberlandesgericht Düsseldorf in its judgment of 26 July 2004 and the French Court of Cassation in its judgment of 15 October 2002). These costs, often borne by the sender or the consignee due to the carrier's inactivity, should still be borne by the latter if they relate to goods which have not arrived at their destination.

The obligation to refund the charges in question cannot cover further financial consequences of damage directly occurring in the consignment. This is due to the provisions of Article 23 (4) of the CMR and Article 30 $\S 4$ of the CIM, which clearly state that no further damage shall be payable. Therefore, expenses incurred for the disposal or storage of goods are not covered by this obligation (however, the Bundesgerichtshof decided differently 
in its judgment of 3 July 1974, in which it considered that the costs of storage of the damaged goods should be covered).

When it comes to the costs of return transport in order to repair a damaged consignment (e.g. by the manufacturer), it should not be forgotten that in accordance with Article 25 of the CMR and Article 32 of the CIM, the compensation for damage to the goods is determined in a way that does not depend on the cost of repair. Sometimes it is more reasonable to sell a damaged item at a reduced price than to repair it. Therefore, the demand to cover the costs of the return transport, as a rule, should be considered unjustified (the following authors argue in favour of the refusal to cover the above costs: (Jesser-Huß, 2009, p. 1079; Koller, 2013, p. 1116; Wesołowski, 2013, p. 540). The English Queen's Bench Division, in its judgment of 22 November 1980, held that it was justified to recover the costs of a return journey where the consignee refused to collect the damaged goods, although in an earlier judgment of 20 November 1973, assumed that the costs of the return of the damaged machine, its storage and inspection were not included in the costs referred to in Article 23 (4) of CMR).

Similarly, contractual penalties or damages paid by the sender or the consignee (e.g. for damages caused by the transported shipment in the property of a third party) cannot be considered as "other charges" within the meaning of the commented provisions.

There are also discrepancies in literature and judicature regarding the costs of taxes, in particular VAT. It should be assumed that if this tax has been paid and the entitled person is not in a position to obtain a refund from the tax office, he may claim from the carrier a refund of the VAT paid under other costs referred to commented provisions. However, a person counting on a tax refund can be a buyer of goods, who did not provide it to the tax office, but paid it to the seller within the price of the purchased goods. Therefore, it is not possible to speak of a tax refund in relation to such a recipient. If he is also entitled to compensation for lost or damaged goods and he cannot be refunded from the tax office for the tax paid in the price of the goods, the compensation for him should be granted (adjudged) at the gross price of the goods, including VAT (the French Cour de Cassation in its judgment of 15 October 2002; the Court de Appeal in Paris in its judgment of 30 March 1973; the Belgian Cour de Cassation in its judgment of 30 May 2002; the Cour de Appel in Anvers in its judgment of 15 June 2009 and in its judgment of 29 June 2009, also applying to excise duties. The Belgian Commercial Cour in Anvers, in its judgment of 12 May 1999, ruled against the reimbursement of VAT. That court limited the costs referred to in Article 23 (4) of the CMR to the costs referred to in Article 6 (1)(i) of the CMR).

With regard to excise duty, attention should also be drawn to the position taken by the House of Lords in its judgment of 9 November 1997. In that judgment, referring also to the French version of the CMR Convention and the rules of interpretation for international law, that court held that a payment for charges incurred in respect of carriage must be interpreted 'meaningfully and broadly' and thus the costs referred to in Article 23 (4) of the CMR also include refund of the excise duty which the beneficiary must pay to the customs authorities in connection with the disappearance of whisky).

\section{Conclusions}

As can be seen from the above considerations, the question of repayment by the carrier of the costs in question is highly debatable. Besides the extreme positions, there is a tendency to search for a compromise interpretation of the provisions constituting the basis for awarding a refund of these charges. Such a view would make it possible to request a refund not only for the costs incurred in connection with the conclusion of the contract 
of carriage, which turned out to be in vain, but also for some other costs incurred after the damage to the goods transported had occurred. First of all, it concerns the costs of carrying out activities which were incumbent on the carrier and which were not carried out by the carrier himself. However, these regulations cannot be the basis for claiming compensation for other damages incurred due to loss or damage to the shipment, such as costs of disposal (neutralisation) of damaged goods, storage costs.

\section{References}

Ambrożuk, D. (2011). Ustalenie wysokości odszkodowania w prawie przewozowy w odniesieniu do przewozu przesyłek. Warszawa: Wolters Kluwer.

CIM - Uniform Rules concerning the Contract of International Carriage of Goods by Rail (CIM) - Appendix B. to Convention concerning International Carriage by Rail (COTIF) of 9 May, as amended by the Vilnius Protocol of 3 June 1999.

Civil Code - the Polish Civil Code of 23 April 1964. Dz.U. of 2018, item 1025.

Clarke, M.A. (2009). International Carriage of Goods by Road: CMR. London: informa.

CMR - Convention on the Contract for the International Carriage of Goods by Road (CMR) of 19 May 1956 with the Protocol of 5 July 1978.

Jesser-Huß, H. (2009). In: B. Czerwenka, R. Herber (eds.), Münchener Kommentar zum Handelsgesetzbuch, Band 7 (pp. 785-1233). München: C.H. Beck/Franz Vahlen.

Kolarski, A. (2002). Prawo przewozowe. Komentarz. Warszawa: C.F. Müller.

Koller, I. (2013). Transportrecht. Kommentar zu Spedition, Gütertransport und Lagergeschäft. München: C.H. Beck.

Loewe, R. (1976). Erläuterungen zum Übereinkommen vom 19. Mai 1956 über den Beförderungsvertrag im Internationalen Strassengüterverkehr (CMR). European Transport Law, 503-597.

Polish Transport Law Act - Polish Transport Law Act of 15 November 1984. Dz.U. of 2017, item 1893.

Rodière, R. (1970). The Convention on Road Transport.. European Transport Law, 306-324.

Wesołowski, K. (2013). Umowa międzynarodowego przewozu drogowego towarów na podstawie CMR. Warszawa: Wolters Kluwer.

\section{Judgments:}

1971.03.31 - judgment of the Cour d'Appeal in Poitiers, Bulletin des Transport 1971, 168.

1973.03.30 - judgment of the Cour d'Appel in Paris, Bulletin des Transport 1975, 193.

1973.11.20 - judgment of English Queen's Bench Division, Lloyd's Law Report 1974, vol. 1, 203-207.

1974.07.03 - judgment of the German Bundesgerichtshof; European Transport Law 1975, 75.

1980.11.22 - judgment of English Queen's Bench Division, Lloyd's Law Report 1981, 200.

1997.11.09 - judgment of the House of Lords, Lloyd's Law Report 1978, vol. 1, 119-135.

1999.05.12 - judgment of the Belgian Commercial Cour d'Anvers, Jurisprudence du Port d'Anvers 1999, 434-439.

1999.06.29 - judgment of the Belgian Tribunal de Commerce in Gand, European Transport Law 2000, 566.

1999.11.18 - judgment of the Rechtbank van Koophandel in Mechelen, European Transport Law 2000, 432.

1999.11.18 - judgment of the Tribunal de Commerce de Malines, European Transport Law 2000, 432-441.

2002.05.30 - judgment of the Belgian Cour de Cassation, European Transport Law 2002, 475-479.

2002.06.07 - judgment of the Cour d'Appel in Anvers, Jurisprudence du Port d'Anvers 2002, 151-158.

2002.10.15 - judgment of the French Cour de Cassation, European Transport Law 2003, 138-141.

2004.07.26 - judgment of the Oberlandesgericht Düsseldorf, Transportrecht 2005, 118-123.

2007.03.14 - judgment of the Oberlandesgericht Düsseldorf, Transportrecht 2007, 199.

2009.06.15 - judgment of the Cour d'Appel in Anvers, European Transport Law 2010, 199-210.

2009.06.29 - judgment of the Cour d'Appel in Anvers, European Transport Law 2010, 182-198.

2009.12.10 - judgment of the German Bundesgerichtshof; European Transport Law 2010, 294-301. 
2011.10.05 - judgment of the French Cour de Cassation, European Transport Law 2012, 110-112.

2015.07.31 - judgment of the Sąd Okręgowy in Łódź, XIII Ga 73/15, not published.

2017.10.27 - judgment of the Sąd Okręgowy in Łódź, XIII Ga 1154/17, not published.

Cite this article aS: Ambrożuk, D. (2018). Charges refunded by the carrier responsible for damage to the consignment. European Journal of Service Management, 4 (28/2), 9-15. DOI: 10.18276/ejsm.2018.28/2-01. 